\title{
Intellectual capital management: An approach to organizational practices in Ecuador
}

\author{
Enrique Claver-Cortés ${ }^{1}$ (D), Patrocinio Zaragoza-Sáez ${ }^{1}$ (D), Mayiya González-Illescas² (iD \\ ${ }^{1}$ University of Alicante (Spain) \\ ${ }^{2}$ Universidad Técnica de Machala (Ecuador) \\ enrique.claver@ua.es,patrocinio.zaragoza@ua.es,mlgonzalez@utmachala.edu.ec
}

Received September, 2017

Accepted January, 2018

\begin{abstract}
Purpose: The present study has as its aim to identify the organizational management practices that involve intellectual capital as facilitators of innovation in its diverse formats, in Ecuador-based shrimp exporting companies.

Design/methodology: The research of a qualitative nature was based on the Grounded Theory as a support for data analysis and collection. The personal interview was used in order to obtain the text corpus. The five resulting clusters served as the basis to apply inductive processes: open coding; axial coding; and selective coding, as a methodological activity meant to help interpret concepts and relationships.
\end{abstract}

Findings: The organizational practices associated with intellectual capital in shrimp exporting companies are focused on structural and human capital management, where innovation has developed from the demands for the implementation of quality management systems in accordance with international regulations.

Research limitations/implications: The main contribution made by the present study lies in establishing a primary reference framework for the design of strategic alternatives that involve strengthening intellectual capital as a way to generate sustainable competitive advantages in the companies belonging to this sector.

Social implications: Shrimp exports, which stand out for being one of the most significant sources of income in Ecuador, contribute to local development by means of employment generation, mainly in rural communities. The exposure to organizational routines linked to intellectual capital provides a chance to come closer to the reality of this sector. This can prove useful for executives and public policy managers to prioritize an approach which influences the generation and maintenance of competitiveness at a firm level, and also impacts on the development of the regions where such business are located.

Originality/value: Faced with the absence of works applied to this sector, the present work explores the reality of shrimp exporting companies, seeking to define a framework for the understanding of intellectual capital management, which might eventually imply a reference point for the design of strategies aimed at strengthening competitive positioning.

Keywords: Intellectual capital, Organizational practices, Innovation, Competitive advantages, Dynamic resources and capabilities 


\section{Introduction}

The present-day economic environment forces companies to face great challenges in their attempts to remain competitive before the changes operated across international markets. Without leaving aside the systemic conception of competitiveness (Mortimore \& Peres, 2001), where companies are supported on an environment which comprises providers and services, as well as systems of standards, to which must be added state policies for the promotion and encouragement of productive activities, the context of a new economy or 'knowledge economy' (Castello, 2002, pp. 197) highlights the need to strengthen intangible assets, so that a response capacity can be prepared to cope with market demands.

The dynamic environment of markets implies new ways to compete, making visible the evolution of perspectives, the passage from traditional schemes which stressed sector structure and value chain to build a sustainable competitive advantage (Porter, 1980) to an approach based on identifying own valuable and idiosyncratic resources (Barney, 1991; Grant, 1991) that can ensure the achievement of better performances in organizations.

The contribution made by the Resource-Based View (Rubin, 1973; Wernerfelt, 1984; Barney, 1991; Grant, 1991) provides the foundations to deal with the generation of competitive advantages from the company's internal assets, which are depicted as resources with their own identity and hard to reproduce (Teece, Pisano \& Shuen 1997), strategic assets which need to be protected and developed (Amit \& Schoemaker, 1993). According to Winter (2003, pp. 991), the implementation of competences and skills combines resources until they become "a collection of routines which characterize the organizational capacity of a company".

The Resource-Based View has a static nature, in the sense that resources are seen as stock; hence the evolution entailed by the approach adopted in the Theory of Dynamic Capabilities when highlighting the importance of renewing and updating resources -a process which implies generating organizational skills-. The essential intangible assets include strategic routines which, insofar as they are organizational practices, may be oriented to a continuous change and adaptation to the environment so that companies can improve their performance (Zahra, Sapienza \& Davidsson, 2006).

Market dynamism obviously poses huge demands for companies, which must act with innovative responses that will depend on the dynamic capabilities which those companies are capable of developing (Claver, Molina \& Zaragoza, 2013). The ability to innovate -as a collective skill of the organization- will be largely influenced by the operations carried out in the form of priority internal processes aimed at ensuring organizational learning, where knowledge implicitly lies. In the light of these theoretical reflections, competitiveness can become apparent in the innovation experienced by companies which introduce changes in their way to do things, for instance, when placing new improved products in the market (López, García \& García, 2012).

Companies immersed in exporting activities keep seeking production factors that can strengthen the generation of lasting competitive advantages over time. In Ecuador, shrimp exports appear as one of the fastest-growing economic activities, generating employment and dynamism in related activities (Banco Central del Ecuador, 2015; Cámara Nacional de Acuacultura, 2015). El Oro Province ranks second in shrimp production at a national level, since its exporting companies stay in international markets fulfilling quality-related regulations and requirements. Hence the central concern in this paper: exploring the reality of companies in order to check if the latter are managing intellectual capital by means of organizational routines that make it possible to generate innovation the key to maintain business competitiveness.

Given the lack of works dedicated to this sector, our research will provide a framework for a better understanding of all that is being done with regard to intellectual capital, which might serve as the basis for the design of strategies aimed at strengthening the competitive positioning of companies. 
Within this background context, the present research has as its purpose to identify organizational management practices which affect intellectual capital as facilitators of innovation in its diverse formats. As an approach to the shrimp exporting sector, our focus will be placed on El Oro Province, which is the second province in Ecuador in terms of national production volume. Our informants were 5 companies -out of the 6 registered oneswhich employ an average of 200 workers each and hold quality certifications.

The paper is structured as follows. After the introduction section, a theoretical review follows, including the literature about the Resource-Based View, an analysis of intellectual capital as a set of intangible assets related to knowledge, the intellectual capital structure, innovation, and the link with organizational capabilities. The third section involves the methodology used, based on the Grounded Theory and the application of the T-Lab software. The paper will finish with the presentation of the results and conclusions regarding the specific organizational practices implemented in relation to intellectual capital components and to the forms of innovation identified. Future lines of research are suggested from the results obtained.

\section{Theoretical foundations}

\subsection{Resource-based view}

Analyzing the factors which determine competitiveness has constituted the focus of interest in business studies for several decades. A variety of approaches have been suggested to provide explanations; thus, the proposal made by Porter (1980) stressed the importance of analyzing the environment, the industrial sectors, and the value chain as contributors to the creation of advantages which consolidate the positioning of companies. Notwithstanding the widespread acceptance of his postulates, the knowledge of the environment did not guarantee the maintenance of business competitiveness over long periods.

The development of several studies (Scott \& Pascoe, 1986; Hansen \& Wernerfelt, 1989; Rumelt, 1991; Roquebert, Phillips \& Westfall, 1996) led to question the model based on the environment to explain competitive advantages, due to the existence of huge differences in profitability between companies belonging to the same industrial sector. Ground was thus progressively gained by research works centered on the internal analysis of companies, the Resource-Based View arising as an alternative to explain the factors with greater potential when it comes to generating competitive advantages.

The Resource-Based View (Rubin, 1973; Wernerfelt, 1984; Barney, 1991; Grant, 1991; Amit \& Schoemaker, 1993; Peteraf, 1993; Collis \& Montgomery, 1995) highlights the existence of resources generated from each company's peculiarities, this origin implying specific features which make them become strategic resources. The possession and utilization of such resources, added to the difficulty involved in their imitation and transfer confers a unique value upon them (Barney, 1991; Peteraf, 1993). This would partly justify the differences in results between companies situated in the same sector.

Resources as static inputs are not valuable in themselves; these resources must be renewed so that they can consistently respond to the changes operated in the environment. That is why the Dynamic Capabilities approach (Teece et al., 1997; Zahra et al., 2006) acknowledges the relevance corresponding to the group of skills which are developed and maintained by the company. They update resources such as knowledge, which in turn makes it possible to adopt better decisions that result in the combination of production factors. Therefore, resources and capabilities become essential not only to define the company's identity but also to reach a competitive advantage despite the rapid changes occurred in the environment (Rumelt, 1991; Teece, Pisano \& Shuen, 1997; Castiaux, 2012).

\subsection{Intellectual capital as a set of intangible assets related to knowledge}

Taking as a reference the availability of intangible assets in the company, organizational knowledge is given the consideration of a strategic resource, which is described as a production factor by Nonaka (1994) and recognized by Drucker (1993) as the fourth element, displacing the 'land,' 'capital', and 'work' factors within a new knowledge-based society. Hence the review of associated studies reveals that knowledge management processes 
occupy an important space in the business sphere, insofar as they positively influence the generation of differentiation attributes and the improvement of business results (Grant, 1991; Calero, 1999; Bueno, 2004; Claver, López, Molina \& Zaragoza, 2004).

A change of perspective has emerged which stresses the value of companies based on their intangibles, and not on that of tangibles as it had traditionally been the case. Sveiby (2001) adds that the discussion about the formulation of strategies must start by considering the competences of individuals, being the set of human actions the ones that lead to produce tangibles and intangibles, where knowledge and its transfer are considered the driving force behind organizational processes.

According to Stewart and Zadunaisky (1998), intellectual capital is a set of immaterial, valuable assets which lie in employees' joint possession, in the sum of experience, skills, knowledge, and information. It is around this possession that the generation and maintenance of competitive advantages becomes possible (Bueno, 1998).

The literature shows authors which define intellectual capital around assets that are most valuable to the company (Itami \& Roehl, 1991; Ross \& Ross, 1997; Edvinsson \& Malone, 1999; Kalkan, Bozkurt \& Alman, 2014) and with the potential to generate economic value, such as knowledge (Lev, 2001), which stands out as a high-strategic-value resource, even though its identification is not easy for the purposes of companies' accounting information.

Intellectual capital reflects the organizational skill and ability to renew knowledge, until the latter is transformed into new resources, which can be used by the company (Edvinsson, 2000). This implies exploiting knowledge with the aim of creating a visible value in the market, as can be product and process innovation.

The combination of intangible assets is the referent utilized by Brooking (1996) in order to describe intellectual capital. This combination would be formed by patents, brands, and royalties, in addition to intangibles generated in a corporate culture such as the skill developed in the administration of operations or strengths derived from using technology. Along the same lines, Edvinsson and Malone (1999) recognize organizational knowledge, customer satisfaction, product innovation, and employees' morale amongst other intangible assets.

In accordance with the relevant literature, it is assumed from this research that intellectual capital goes beyond intangible resources such as the knowledge accumulated by the organization at a given time or the continuous actions which reflect collective skills to articulate, combine, and adapt internal as well as external elements, in response to the changes required by the competitive environment.

The multiplier effects of intellectual capital in organizations is additionally recognized when it comes to knowledge generation and renewal, an outstanding role corresponding to collaborators in the company who, thanks to their competences and know-how, gradually shape knowledge via organizational learning (Edvinsson, 2000). Hence the importance of implementing knowledge management to orient the generation of dynamic capabilities which, being implicit in intellectual capital, boost innovation from multiple perspectives.

In the light of these approaches, a decision was made to adopt knowledge management as the set of activities which characterize internal practices to create, develop, and transfer knowledge, this being recognized as a "systematic value creation process" (Briceño \& Bernal, 2010, pp. 179) which enhances the ability to solve problems and generate associated creative responses within a given context.

\subsection{Intellectual capital structure}

Literature about intellectual capital provide several models which reflect a coincidence between authors. The most widely accepted one (Saint-Onge, 1996; Edvinsson \& Malone, 1999; Petty \& Guthrie, 2000; Bontis \& Fitzenz, 2002; Ordóñez de Pablos, 2003) shows intellectual capital as consisting of three components: human capital; structural capital; and relational capital.

Other authors agree on the inclusion of additional components such as innovation capital (Wiig, 1997; McElroy, 2002; Chen, Zhu \& Hong, 2004; Yang \& Kang, 2008), which refers to a company's collective capacity for 
innovation. The social capital approach is also incorporated (Nahapiet \& Ghoshal, 1998; Adler \& Kwon, 2002; Macpherson \& Holt, 2007; Zheng, 2010), understanding that social capital as the set of values, moral, rules, trust, and vision shared inside a group which become visible in the informal relationships that take place and make cooperation between members possible. Once its components have been articulated and set in motion, social capital becomes a facilitator for the knowledge creation process (Nahapiet \& Ghoshal, 1998).

In practice, intellectual capital components are related (Edvinsson \& Malone, 1999; Ordóñez de Pablos, 2003) and attention must be paid to their articulation when designing and executing strategies aimed at strengthening them. In other words, the identification of intellectual capital dimensions does not mean that management has to be undertaken separately. Rastogi (2002) emphasizes the fact that the combination described above leads the organization to develop capabilities and skills for the purpose of taking advantage of the opportunities which create value for the company. Table 1 brings together the contributions made by several authors with respect to the intellectual components.

\begin{tabular}{|l|l|l|l|l|}
\hline Author & Year & Human Capital & Structural Capital & Relational Capital \\
\hline Kaplan \& Norton & 1993 & $\begin{array}{l}\text { Knowledge and growth } \\
\text { perspective }\end{array}$ & $\begin{array}{l}\text { Internal processes } \\
\text { perspective }\end{array}$ & Customers perspective \\
\hline Sveiby & 1997 & Competences & Internal structure & External structure \\
\hline Edvinsson \& Malone & 1997 & $\begin{array}{l}\text { Employees' } \\
\text { competences, ability to } \\
\text { interrelate, values }\end{array}$ & $\begin{array}{l}\text { Processes, organizational } \\
\text { structure, coded } \\
\text { knowledge, organizational } \\
\text { systems; it includes } \\
\text { innovative capital }\end{array}$ & $\begin{array}{l}\text { Focus on customers, the } \\
\text { relationships that the } \\
\text { company maintains with } \\
\text { customers and other } \\
\text { external agents? create value }\end{array}$ \\
\hline Bontis & 2001 & $\begin{array}{l}\text { Competences, } \\
\text { knowledge, skills, } \\
\text { collective ability, } \\
\text { behavior }\end{array}$ & $\begin{array}{l}\text { Databases, organization } \\
\text { charts, process manuals, } \\
\text { strategies, routines, } \\
\text { systems, procedures. } \\
\text { Technological component }\end{array}$ & $\begin{array}{l}\text { Knowledge incorporated } \\
\text { into the channels for } \\
\text { commercialization and } \\
\text { relationships with customers }\end{array}$ \\
\hline Chen, Zhu \& Hong & 2004 & $\begin{array}{l}\text { Employees' knowledge, } \\
\text { skill, ability, and attitudes }\end{array}$ & $\begin{array}{l}\text { Structure which helps } \\
\text { employees achieve a } \\
\text { business performance }\end{array}$ & $\begin{array}{l}\text { Commercialization } \\
\text { relationships; value is } \\
\text { incorporated from channels }\end{array}$ \\
\hline $\begin{array}{l}\text { Intellectus Model } \\
\text { Bueno, Salmador \& Merino }\end{array}$ & 2008 & $\begin{array}{l}\text { Human capital } \\
\text { ingapital and social }\end{array}$ \\
\hline
\end{tabular}

Table 1. Intellectual Capital Structure

Based on the theoretical review, our research in this paper adopts the intellectual capital structure with the components 'human capital,'structural capital,' and 'relational capital.'Human capital refers to employees' skills, to the experience, knowledge, know-how, values, and attitudes of individuals, and it appears as the most important intangible asset that an organization can have (Kalkan et al., 2014), turning out to be a key element when it comes to achieving organizational improvements (Schultz, 1993). In turn, structural capital has to do with the internal processes, infrastructures, information systems, culture, routines, and procedures for human capital to be productive (Ross \& Ross, 1997). As for relational capital, it becomes apparent in the relationship that the company maintains with the external environment, as well as in the relationships with customers, strategic partners, providers, distributors, investors, public bodies, and other stakeholders that have some bearing on the company's life (Todericiu \& Stănit, 2015).

\subsection{Innovation, a vision from capabilities and processes}

Economic thinking has considered innovation a source of development and economic growth throughout history. Schumpeter (1912) used his work entitled The Theory of Economic Development to propose a model through which the production level depends on the combination of labor, resources, capital, and technological progress. Precisely this last element, technological progress, is associated with innovation, presented as a factor 
that allows explaining the difference in growth rates (Lucas, 1988; Romer, 1990; Barro \& Sala-i-Martin, 1997; Holcombe, 1998).

The conception of innovation has been approached from different points of view. Schumpeter (1912) highlighted the importance of novelty as a determining factor for innovation, considering as such from the incorporation of new products, production methods, markets, and raw materials, to new forms of organization. Damanpour (1991) drew a distinction between:

- technological innovation, referred to changes in services and products, closely linked to novelties in the technology applied or developed to obtain them; and

- administrative innovation, related to the human resource activities and functions of the human resource that serve as the main support for the organization.

Innovation is not confined to new product creation; it takes other forms, including "innovative processes, organizational structure, systems management, innovative business models, and differentiation in the service delivered to customers" (Aryanto, Fontana \& Afiff, 2015, pp. 875). The incorporation of technological advances constitutes a clear expression of innovation. However, just the availability of technology resources will not lead to the generation of competitive advantages (Bharadwaj, 2000), being necessary a human component with the capabilities and skills needed to implement and use them.

March (1991) mentioned exploitation and exploration capacities as a source of business innovation. The exploitation capacity implies searching for improvements from the resources, knowledge, and capabilities available in the organization. Instead, the exploration capacity has to do with an attitude of 'opening' to experiment with other external alternatives that entails collaboration with other companies (Lee, Park, Yoon \& Park, 2010; Huizingh, 2011). This leads these business to prioritize the continuous creation of internal competences (Clausen, Pohjola, Sapprasert \& Verspagen, 2011; Madsen \& Leiblein, 2015) where dynamic resources and capabilities arise as strengths to generate competitiveness via innovation.

Innovation generation is associated with the existence of a favorable environment for learning and creativity, being recognized a direct influence on business results (Damanpour, 1996; Griffin, 1997; Ernst 2002; Rasmussen, 2014). Along this same line of reasoning, Abramovitz (1986) identifies the need to promote capabilities on a company basis, such as educational level, business organization or degree of opening, all of them elements that would permit to capture the advances achieved in the environment with regard to the aim of generating innovation in production processes.

Linking the definitions presented above allows us to assume that the capabilities developed by the human resource within an organization, together with their management, make it possible to create new products and processes, thus strengthening the link between intellectual capital and innovation. Organizational innovation as a result is obtained from learning processes that promote knowledge development (Naranjo, Jiménez \& Sanz, 2006) and capabilities that make possible both team work and communication, as well as adaptation to change. In short, complex organizational capabilities conferring characteristics which are hard to identify and reproduce by competitors.

The literature review presented and the research aim, starting from the premise that our proposal implies an approach to the Ecuadorean reality from the shrimp sector, allows us to pose the following research questions:

Which elements are perceived as competitiveness generators in the companies under study?

What type of organizational practices strengthen intellectual capital management?

What sort of innovation becomes visible in the organizational practices identified?

An effort will be made to answer these questions in the following sections. 


\section{Methodology}

Our starting point is an analysis model based on the literature review which shows the components of intellectual capital, along with its relationship with knowledge and innovation.

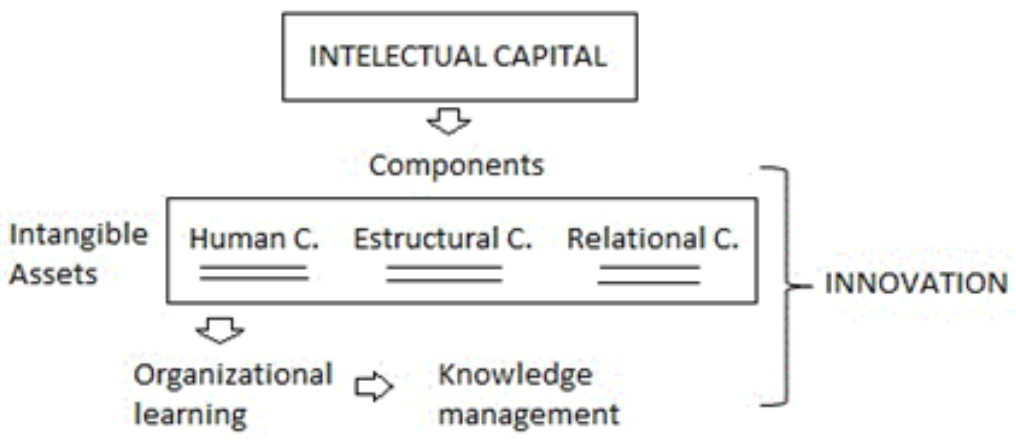

Figure 1. Analysis Model

The Grounded Theory (Glaser,1992; Glaser \& Strauss, 1967; Martin \& Turner, 1986; Strauss \& Corbin, 1990; Locke, 1996, 2005) served as the basis of qualitative research, seen as a methodological alternative for data analysis and collection characterized by its scientific rigor which uses inductive processes to capture the theory emerging from the actors located in a real context, from which arise their interpretations about the examined phenomena. The Grounded Theory has been applied in multiple case studies (Eisenhardt, 1989; Brown \& Eisenhardt, 1997; Partington, 2000; Eisenhardt \& Graebner, 2007), in the fields of innovation (Macrì, Tagliaventi \& Bertolotti, 2002), knowledge management (Hunter, Hari, Egbu \& Kelly, 2005), knowledge transfer and organizational climate (Hajro, Gibson \& Pudelko, 2017), and dynamic capabilities (Eisenhardt \& Graebner, 2007; Donada, Nogatchewsky \& Pezet, 2016).

Data analysis is limited to interpretation, a process in which both concepts and relationships can be identified. The methodological tasks considered in the Grounded Theory -open coding; axial coding; and selective coding (Strauss \& Corbin, 1990; Hajro, Gibson \& Pudelko, 2017)-are used to identify organizational practices and also to locate them according to their connection with intellectual capital dimensions.

Given the qualitative dimension of the perception that the individuals involved in human talent management had about intellectual capital, the software T-Lab version 8 was used seeking to provide support for data analysis within the framework of the text corpus. This tool provides statistical, graphic, and content-analysis-related applications through the identification of word patterns.

As for the sector analyzed, the shrimp production and export activity in Ecuador, it revitalizes the economy by means of employment generation. It ranks the second level of income in primary product exports, only after bananas. This sector, which comprises 39 exporting companies and1,315 nationwide shrimp producers, generates around 250,000 jobs between direct and indirect ones (Cámara Nacional de Acuacultura, 2015), 60\% of which are located in rural areas.

Since the study object was the management of intellectual capital in shrimp exporting companies belonging to El Oro Province, the selection of companies was clearly determined by their predisposition to collaborate. 5 of the 6 exporters registered at the Instituto Nacional de Pesca [National Fishing Institute] agreed to participate, being their human talent managers as well as those responsible for the areas of quality management, security, and industrial hygiene, our informants. The companies which took part in our study share the following characteristics: presence in international markets; more than 200 employees on average in each one of them; international quality certifications; added-value products; and over five years of operation. 
Personal interview was the technique chosen to obtain the information. Following Strauss and Corbin (1990), a decision was made to use an initial question guide with open questions and not a structured questionnaire, in order to be able to interpret whatever the actors consider relevant. Concepts and relationships emerged in the course of the interview, thus sequentially giving rise to further questions.

The initial guide was designed with the following questions related to intellectual capital management and innovation (see Table 2):

\begin{tabular}{|c|c|c|}
\hline Questions & \multicolumn{2}{|c|}{$\begin{array}{l}\text { Conceptual aspect with which it is } \\
\text { associated }\end{array}$} \\
\hline $\begin{array}{l}\text { Considering the company's experience as an exporter, which are the } \\
\text { elements that you view as competitive advantages to stay in international } \\
\text { markets? }\end{array}$ & \multirow{2}{*}{\multicolumn{2}{|c|}{ Global competitiveness of the company }} \\
\hline $\begin{array}{l}\text { Which aspects have been essential to achieve a positioning in international } \\
\text { markets from your point of view? }\end{array}$ & & \\
\hline $\begin{array}{l}\text { In relation to human capital and its participation, which activities are } \\
\text { managed in greater depth? }\end{array}$ & \multirow{3}{*}{$\begin{array}{l}\text { Intellectual } \\
\text { Capital } \\
\text { Dimensions }\end{array}$} & Human Capital \\
\hline $\begin{array}{l}\text { What type of relationships has the company developed with external } \\
\text { agents? }\end{array}$ & & Relational Capital \\
\hline What role does organizational culture play in the company's performance? & & Structural Capital \\
\hline Which aspects do you consider expressions of innovation in the company? & \multicolumn{2}{|c|}{ Innovation } \\
\hline
\end{tabular}

Table 2. Interview Structure

\section{Results}

Five interviews were applied, and the text corpus under analysis consisted of 125 elementary contexts or paragraphs. The implementation of the T-Lab software by means of automatic analysis leads to obtain an arrangement of accounts in five clusters, which represent the association of keywords. In other words, a cooccurrence appears which serves to bring us closer to the semantic content. Table 3 highlights the composition of the resulting clusters through the analysis of the data obtained from the interview with the exporting companies belonging to the shrimp sector based on El Oro Province.

In an attempt to interpret results, Table 4 shows the analysis of clusters derived from applying the T-Lab software. The repetition of words is associated with broad categories here, which makes it possible to approach an open coding as the fruit of a primary reflection process. The passage to axial coding implied deepening into discourse review for the purpose of identifying constructs related to the primary category identified.

\begin{tabular}{|c|c|c|c|c|}
\hline Cluster No. & $\begin{array}{l}\text { Number of } \\
\text { paragraphs }\end{array}$ & $\begin{array}{l}\text { Lemma or } \\
\text { keywords }\end{array}$ & $\begin{array}{l}\text { Number of times } \\
\text { included in the cluster }\end{array}$ & $\begin{array}{l}\text { Number of times included } \\
\text { in the total of clusters }\end{array}$ \\
\hline \multirow{5}{*}{ Cluster $1(15.45 \%)$} & \multirow[t]{5}{*}{$1 \quad 01$} & Staff & 13 & 27 \\
\hline & & Quality & 12 & 39 \\
\hline & & Team & 6 & 9 \\
\hline & & Time & 6 & 12 \\
\hline & & Control & 5 & 8 \\
\hline \multirow{6}{*}{ Cluster $2(21.14 \%)$} & \multirow{6}{*}{26} & Training & 17 & 49 \\
\hline & & Knowledge & 12 & 12 \\
\hline & & Staff & 11 & 27 \\
\hline & & Talent & 7 & 16 \\
\hline & & Security & 5 & 9 \\
\hline & & Certifiers & 3 & 4 \\
\hline \multirow{6}{*}{ Cluster $3(17.89 \%)$} & \multirow{6}{*}{22} & Process & 9 & 26 \\
\hline & & Certification & 7 & 14 \\
\hline & & Exigency & 5 & 5 \\
\hline & & Consultants & 4 & 5 \\
\hline & & Improvement & 3 & 6 \\
\hline & & Manage & 3 & 4 \\
\hline
\end{tabular}




\begin{tabular}{|c|c|c|c|c|}
\hline Cluster No. & $\begin{array}{l}\text { Number of } \\
\text { paragraphs }\end{array}$ & $\begin{array}{l}\text { Lemma or } \\
\text { keywords }\end{array}$ & $\begin{array}{l}\text { Number of times } \\
\text { included in the cluster }\end{array}$ & $\begin{array}{l}\text { Number of times included } \\
\text { in the total of clusters }\end{array}$ \\
\hline \multirow{6}{*}{ Cluster $4(24.39 \%)$} & \multirow{6}{*}{30} & Training & 19 & 49 \\
\hline & & Market & 19 & 30 \\
\hline & & International & 12 & 25 \\
\hline & & Plan & 6 & 7 \\
\hline & & Planning & 4 & 4 \\
\hline & & Education & 3 & 4 \\
\hline \multirow{5}{*}{ Cluster $5(21.14 \%)$} & \multirow{5}{*}{26} & Shrimp & 14 & 20 \\
\hline & & Partner & 6 & 7 \\
\hline & & Capacity & 5 & 8 \\
\hline & & Produce & 4 & 5 \\
\hline & & Export & 3 & 5 \\
\hline
\end{tabular}

Table 3.Cluster Composition

\begin{tabular}{|c|c|c|c|}
\hline \multicolumn{4}{|c|}{ SELECTIVE CODING } \\
\hline \multirow{2}{*}{ Open Coding } & \multicolumn{2}{|c|}{ Axial Coding } & \multirow{2}{*}{ Management Practices } \\
\hline & Components & Variables & \\
\hline $\begin{array}{l}\text { Organizational } \\
\text { learning }\end{array}$ & \multirow{5}{*}{$\begin{array}{l}\text { Human } \\
\text { Capital }\end{array}$} & Training & $\begin{array}{l}\text { Knowledge is generated from training schemes with external } \\
\text { advisors. External knowledge acquired }\end{array}$ \\
\hline $\begin{array}{l}\text { Knowledge } \\
\text { transfer }\end{array}$ & & Transfer & $\begin{array}{l}\text { Training schemes improve human talent performance. } \\
\text { Transfer from advisors' coded knowledge, ISO 9001quality } \\
\text { management norms }\end{array}$ \\
\hline \multirow{3}{*}{$\begin{array}{c}\text { Experience } \\
\text { ontraining }\end{array}$} & & \multirow{3}{*}{ Experience } & $\begin{array}{l}\text { Training schemes are related to time saving and a reduction of } \\
\text { waste and costs }\end{array}$ \\
\hline & & & $\begin{array}{l}\text { Replicationof the training scheme for key staff with potential } \\
\text { and responsibility }\end{array}$ \\
\hline & & & Induction program with experienced staff \\
\hline \multirow{3}{*}{$\begin{array}{c}\text { Quality } \\
\text { management }\end{array}$} & \multirow{7}{*}{ Structural Capital } & \multirow{3}{*}{$\begin{array}{l}\text { Internal } \\
\text { processes }\end{array}$} & Quality Management Systems implemented \\
\hline & & & $\begin{array}{l}\text { Continuous training in quality legislation, quality management } \\
\text { systems, and production processes }\end{array}$ \\
\hline & & & Changes in processes identified and suggested internally \\
\hline \multirow{4}{*}{$\begin{array}{l}\text { Continuous } \\
\text { improvement } \\
\text { processes }\end{array}$} & & \multirow{4}{*}{$\begin{array}{l}\text { Organizational } \\
\text { culture }\end{array}$} & International Quality Standards implemented \\
\hline & & & $\begin{array}{l}\text { Documented processes pursuant to international quality } \\
\text { regulations }\end{array}$ \\
\hline & & & Commitment within the framework of quality management \\
\hline & & & Quality policy monitoring \\
\hline \multirow{5}{*}{$\begin{array}{l}\text { Relationship } \\
\text { with the } \\
\text { environment }\end{array}$} & \multirow{5}{*}{$\begin{array}{l}\text { Relational } \\
\text { Capital }\end{array}$} & $\begin{array}{l}\text { Relationships } \\
\text { with customers }\end{array}$ & $\begin{array}{l}\text { Companies carry out a constant monitoring of the market, the } \\
\text { implementation of quality standards provides evidence } \\
\text { thereof }\end{array}$ \\
\hline & & \multirow{4}{*}{$\begin{array}{l}\text { Relationships } \\
\text { with providers }\end{array}$} & $\begin{array}{l}\text { The companies belonging to this sector have maintained } \\
\text { growing sales during the last } 5 \text { years. }\end{array}$ \\
\hline & & & They have increased markets and customers \\
\hline & & & $\begin{array}{l}\text { Relationship with technology and feedproviders and } \\
\text { consultancy for quality certifications }\end{array}$ \\
\hline & & & $\begin{array}{l}\text { Relationship with governmental institutions to update the } \\
\text { regulation, as well as the criteria for quality and training }\end{array}$ \\
\hline \multicolumn{4}{|c|}{ Evidence of innovation in the companies under observation } \\
\hline \multicolumn{3}{|c|}{ Changes in organizational processes } & $\begin{array}{l}\text { Substantial improvement in planning, control, and } \\
\text { management practices }\end{array}$ \\
\hline \multicolumn{3}{|c|}{ Production facilities modernization } & Significant changes in infrastructure, equipment, and tools \\
\hline \multicolumn{3}{|c|}{$\begin{array}{l}\text { Implementation of a quality-oriented organizational } \\
\text { culture }\end{array}$} & $\begin{array}{l}\text { Policies, procedures, empowered work teams, and incentives } \\
\text { for the participation of collaborators }\end{array}$ \\
\hline
\end{tabular}

Table 4. Intellectual capital in the shrimp exporting companies based on El Oro province

Seeking to achieve a more comprehensive understanding of the perception about intellectual capital management, a review was carried out of the words repeated in the discourse used by the interviewees to answer the question about the factors that, in their view, contribute to generate competitive advantages. A link arises therefrom with the most frequent organizational practices, and the innovation derived from applying the changes 
operated in the internal processes linked to improvements in planning and control practices, quality management from an organizational culture and changes in infrastructure, equipment and tools. All these characteristics arise as homogeneous elements in the companies that took part in our study.

The main constructs are finally located into the intellectual capital components. This systematic process of analytical and reflexive exercise results in the emergence of a theory which consists in the configuration of intellectual capital management linked to the components which mostly constitute the focus of interest for organizational practices in the shrimp exporting companies located in El Oro Province, and the expressions of innovations perceived.

\section{Conclusions and discussion}

The present paper had as its aim to identify the organizational practices involving intellectual capital as a predominant factor in the generation of innovation, within the context of the shrimp exporting companies located in El Oro Province. Guided by the research questions proposed, the answers are approached from the following conclusions.

\section{Competitiveness factors}

According to the perception of the individuals in charge of the companies included in ourstudy, competitiveness is supported on compliance with the demanding international quality standards, which entailed the need to undertake adaptations in infrastructure, as well as in productive and administrative processes.

\section{Intellectual capital organizational practices referred to the human capital dimension}

In parallel to the implementation of quality management systems, the present paper has shown an approach based on training programs as part of the strategy to respond to the changes required by the use of new equipment, instruments, processes and parameters of production. Experience about professional training is highly valued and the staff that performs activities in the production area has been trained in-house. This criterion remains homogeneous in the units observed, a transfer of tacit knowledge on the explicit one being reflected.

\section{Intellectual capital organizational practices referred to the structural capital dimension}

The approach followed in quality management systems and compliance with international regulations has led the companies belonging to the shrimp sector to implement organizational changes which are expressed in a number of processes and their control. Emphasis is placed on the strengthening of an organizational culture, headed by the management's commitment, which has reinforced competences by means of training and teamwork programs.

According to the above, it is concluded that, from the intellectual capital management perspective, a predominance of activities related to structural capital exists, followed by human capital, insofar as interviewees think that both the innovation perceived and the changes implemented have led to obtain positive results such as cost optimization and time reduction.

\section{Intellectual capital organizational practices referred to the relational capital dimension}

The constant monitoring of market manifestations and specific requirements of customers has impacted on the preparation to respond from production and quality control processes, adapting the offer to the demands posed by regulations. Despite the failure to detect dynamic processes oriented towards innovation and new product launch, three of the five exporting companies keep added value products in their portfolio, which has led them to maintain -and open- new markets.

From the relational capital management perspective, advantage is taken of the contact with private providers to strengthen the utilization of high-quality control equipment, shrimp feeding programs, and advice for the implementation of quality management systems. The relationship with the public sector becomes apparent in the 
alliances with institutions that define regulatory and control systems, both in the healthcare context and in that of taxes, mainly with regard to updating and cooperation.

\section{Innovation}

Export activity demands from companies that they maintain high quality levels in processes and products. Innovation has become evident in the changes introduced in the forms of work, information arrangement, equipment and production control, renovation and adaptation of facilities, tools. In short, an emphasis is placed on the adaptation of the product to international quality standards, rather than on new products for markets. To which must be added that teamwork organization and the greater involvement of workers in decision-making reflects a change in the organizational culture of the exporting companies under study.

\section{Limitations and future research lines}

The aim sought with this paper consisted in characterizing the perception that managers have with regard to intellectual capital, competitiveness, and innovation, from their shrimp exporting companies. Since attention is paid to the current organizational practices, it seems to us that the main contribution made by the present study lies in establishing a primary reference framework for the design of strategic alternatives that involve strengthening intellectual capital as a way to generate sustainable competitive advantages in the companies belonging to this sector.

The main limitation of the study has to do with the qualitative research, which does not allow generalizing the results to a wider population. A recommendation is made to apply an exploratory and confirmatory analysis, broadening the sample to producers that act as providers of the largest exporting companies, and considering control variables such as size, age, and production volume.

As for future lines of research, it seems advisable to expand the study, from company managers towards the vision of the staff as a whole, in relation to intellectual capital and its management, incorporating multivariate analysis for the purpose of identifying the variables which turn out to be more influential in their performance.

\section{Declaration of Conflicting Interests}

The author declared no potential conflicts of interest with respect to the research, authorship, and/or publication of this article.

\section{Funding}

The authors received no financial support for the research, authorship, and/or publication of this article.

\section{References}

Abramovitz, M. (1986). Catching up, forging ahead, and falling behind. The Journal of Economic History, 46(02), 385-406. https://doi.org/10.1017/S0022050700046209

Amit, R., \& Schoemaker, P. (1993). Strategic Assets and Organizational Rent. Strategic Management Journal, 14(1), 33-46. https://doi.org/10.1002/smj.4250140105

Aryanto, R., Fontana, A., \& Afiff, A. (2015). Strategic Human Resource Management, Innovation Capability and Performance: An Empirical Study in Indonesia Software Industry. Procedia Social and Behavioral Sciences, 211(9), 874-879. https://doi.org/10.1016/j.sbspro.2015.11.115

Banco Central del Ecuador. (2015). Exportaciones por actividad económica. Retrieved from: https://www.bce.fin.ec/

Barney, J. (1991). Firm Resources and Sustained Competitive Advantage. Journal of Management, 17(1), 99-120. https://doi.org/10.1177/014920639101700108

Barro, R. \& Sala-i-Martin, X. (1997). Technological diffusion, convergence and growth. Journal of Economic Growth, 2(1), 1-26. https://doi.org/10.1023/A:1009746629269 
Bharadwaj, A. (2000). A resource-based perspective on information technology capability and firm performance: An empirical investigation. MIS Quarterly, 169-196. https://doi.org/10.2307/3250983

Bontis, N. (2001). Assessing knowledge assets: A review of the models used to measure intellectual capital. International Journal of Management Reviews, 3(1), 41-60. https://doi.org/10.1111/1468-2370.00053

Bontis, N., \& Fitz-enz, J. (2002). Intellectual capital ROI: A causal map of human capital antecedents and consequents. Journal of Intellectual Capital, 3(3), 223-247. https://doi.org/10.1108/14691930210435589

Briceño, M., \& Bernal, C. (2010). Estudios de caso sobre la gestión del conocimiento en cuatro organizaciones colombianas líderes en penetración de mercado. Estudios Gerenciales, 26(117), 173-193. https://doi.org/10.1016/S0123-5923(10)70140-6

Brooking, A. (1996). Intellectual Capital: Core Assets for the Third Millennium Enterprise. London: Thompson Business Press.

Brown, S., \& Eisenhardt, K. (1997). The art of continuous change: Linking complexity theory and time-paced evolution in relentlessly shifting organizations. Administrative Science Quarterly, 42, 1-34.

Bueno, C. (1998). El capital intangible como clave estratégica en la competencia actual. Boletín de Estudios Económicos, 53, 207-229.

Bueno, E. (2004). Dirección del conocimiento organizativo. propuesta terminológica para estudiar el desarrollo, medición y gestión de intangibles en las organizaciones. AECA. Revista de la Asociación Española de Contabilidad y Administración de Empresas, 68, 39-40.

Bueno, E., Salmador, M., \& Merino, C. (2008). Génesis, concepto y desarrollo del capital intelectual en la economía del conocimiento: Una reflexión sobre el Modelo Intellectus y sus aplicaciones. Estudios de Economía Aplicada, 26(2), 43-63.

Calero, J. (1999). Sobre gestión del conocimiento, un intangible clave en la globalización. Economía Industrial, 330, 61-70.

Cámara Nacional de Acuacultura. (2015). Ecuador apuesta a la calidad con el mejor camarón del mundo. Retrieved from: http://www.cna-ecuador.com/

Castello, E. (2002). Los activos intangibles en la era del conocimiento. Boletín de Estudios Económicos, 57(176), 197-226.

Castiaux, A. (2012). Developing dynamic capabilities to meet sustainable development challenges. International Journal of Innovation Management, 16(6), 1-16. https://doi.org/10.1142/S1363919612400130

Chen, J., Zhu, Z., \& Hong, Y.X. (2004). Measuring intellectual capital: A new model and empirical study. Journal of Intellectual Capital, 5(1), 195-212. https://doi.org/10.1108/14691930410513003

Clausen, T., Pohjola, M., Sapprasert, K., \& Verspagen, B. (2011). Innovation strategies as a source of persistent innovation. Industrial and Corporate Change, 21(3), 553-585. https://doi.org/10.1093/icc/dtr051

Claver, E., López, M., Molina, J., \& Zaragoza, P. (2004). La integración del capital medioambiental en el capital intelectual de la empresa. Revista de Economía y Empresa, 21(50), 11-28.

Claver, E., Molina, H., \& Zaragoza, P. (2013). El efecto dinamizador del capital intelectual en la innovación de las empresas familiares. Economía Industrial, (388), 121-128.

Collis, D., \& Montgomery, C. (1995). Competing on Resources: Strategy in the 1990s. Harvard Business Review, 73, 118-128.

Damanpour, F. (1991). Organizational innovation: A meta-analysis of effects of determinants and moderators. Academy of Management Journal, 34(3), 555-590. https://doi.org/10.2307/256406

Damanpour, F. (1996). Organizational complexity and innovation: Developing and testing multiple contingency models. Management Science, 42, 693-716. https://doi.org/10.1287/mnsc.42.5.693 
Donada, C., Nogatchewsky, G., \& Pezet, A. (2016). Understanding the relational dynamic capability-building process. Strategic Organization, 14(2), 93-117. https://doi.org/10.1177/1476127015615286

Drucker, P. (1993). The rise of the knowledge society. Wilson Quarterly, 17(2), 52-71.

Edvinsson, L. (2000). Some perspectives on intangibles and intellectual capital 2000. Journal of Intellectual Capital, 1(1), 12-16. https://doi.org/10.1108/14691930010371618

Edvinsson, L., \& Malone, M. (1997). Intellectual Capital. New York: Harper Business.

Edvinsson, L. \& Malone, M. (1999). El Capital Intelectual. Barcelona: Gestión 2000.

Eisenhardt, K. (1989). Building theories from case study research. Academy of Management Review, 14(4), 532-550.

Eisenhardt, K., \& Graebner, M. (2007) Theory Building from Cases: Opportunities and Challenges. Academy of Management Journal, 50(1), 25-32. https://doi.org/10.5465/AMJ.2007.24160888

Ernst, H. (2002). Success factors of new product development: A review of the empirical literature. International Journal of Management Reviews, 4, 1-40. https://doi.org/10.1111/1468-2370.00075

Glaser, B. (1992) Basics of grounded theory analysis: emerge vs. forcing. California: Sociology Press.

Glaser, B., \& Strauss, A. (1967). The Discovery of Grounded Theory: Strategies for Qualitative Research. New York: Aldine de Gruyter.

Grant, R. (1991). The Resource-Based Theory of Competitive Advantage: Implications for Strategy Formulation. California Management Review, 33(3), 114-135. https://doi.org/10.2307/41166664

Griffin, A. (1997). PDMA research on new product development practices: updating trends and benchmarking best practices. Journal of Product Innovation Management, 14, 429-458. https://doi.org/10.1016/S07376782(97)00061-1

Hajro, A., Gibson, C., \& Pudelko, M. (2017). Knowledge Exchange Processes in Multicultural Teams: Linking Organizational Diversity Climates to Teams' Effectiveness. Academy of Management Journal, 60(1), $345-372$. https://doi.org/10.5465/amj.2014.0442

Hansen, G., \& Wernerfelt, B. (1989). Determinants of firm performance: The relative importance of economic and organizational factors. Strategic Management Journal, 10(5), 399-411. https://doi.org/10.1002/smj.4250100502

Holcombe, R. (1998). Entrepreneurship and economic growth. The Quarterly Journal of Austrian Economics, 1(2), 45-62. https://doi.org/10.1007/s12113-998-1008-1

Huizingh, E. (2011). Open innovation: State of the art and future perspectives. Technovation, 31(1), 2-9. https://doi.org/10.1016/j.technovation.2010.10.002

Hunter, K., Hari, S., Egbu, C., \& Kelly, J. (2005). Grounded theory: Its diversification and application through two examples from research studies on knowledge and value management. The Electronic Journal of Business Research Methodology, 3(1), 57-68.

Itami, H., \& Roehl, T. (1991). Mobilizing invisible assets. EE.UU: Harvard University Press.

Kalkan, A., Bozkurt, Ö., \& Arman, M. (2014). The Impacts of Intellectual Capital, Innovation and Organizational Strategy on Firm Performance. Procedia - Social and Behavioral Sciences, 150(34), $700-707$. https://doi.org/10.1016/j.sbspro.2014.09.025

Kaplan, R. \& Norton, D. (1993). Putting the Balanced Scorecard to work. Harvard Business Review (SeptemberOctober), 134-147.

Lee, S., Park, G., Yoon, B. \& Park, J. (2010). Open innovation in SMEs-an intermediated network model. Research Policy, 39, 290-300. https://doi.org/10.1016/j.respol.2009.12.009

Lev, B. (2001). Intangibles: Management, measurement, and reporting. Washington: The Brookings Institution Press. 
López, E., García, F., \& García, S. (2012). De la organización que aprende a la organización ambidiestra: Evolución teórica del aprendizaje organizativo. Cuadernos de Administración, 25(45), 11-37.

Locke, K. (1996). Rewriting the discovery of grounded theory after 25 years?. Journal of Management Inquiry, 5(3), 239-245. https://doi.org/10.1177/105649269653008

Locke, K. (2005). Pragmatic reflections on a conversation about grounded theory in Management and Organization Studies. Organizational Research Methods, 18(4), 612-619. https://doi.org/10.1177/1094428115574858

Lucas, R. (1988). On the mechanics of economic development. Journal of Monetary Economics, 22(1), 3-42. https://doi.org/10.1016/0304-3932(88)90168-7

Macpherson, A., \& Holt, R. (2007). Knowledge, learning and small firm growth: A systematic review of the evidence. Research Policy, 36(2), 172-192. https://doi.org/10.1016/j.respol.2006.10.001

Macrì, D., Tagliaventi, M, \& Bertolotti, F. (2002). A grounded theory for resistance to change in a small organization. Journal of Organizational Change Management, 15(3), 292-310. https://doi.org/10.1108/09534810210429327

Madsen, T., \& Leiblein, M. (2015). What Factors Affect the Persistence of an Innovation Advantage?. Journal of Management Studies, 52(8), 1097-1127. https://doi.org/10.1111/joms.12154

March, J. (1991) Exploration and exploitation in organizational learning. Organization Science, 2(1), 71-87. https://doi.org/10.1287/orsc.2.1.71

Martin, P., \& Turner (1986). Grounded theory and organizational research. The Journal of Applied Behavioral Science, 22(2), 141-157. https://doi.org/10.1177/002188638602200207

McElroy, M. (2002). Social innovation capital. Journal of Intellectual Capital, 3(1), 30-39. Retrieved from: https://search.proquest.com/docview/205537687?accountid=17192 https://doi.org/10.1108/14691930210412827

Mortimore, M., \& Peres, W. (2001). La competitividad empresarial en América Latina y el Caribe. Revista de la CEPAL, 74(8), 37-59.

Nahapiet, J., \& Ghoshal, S. (1998). Social capital, intellectual capital, and the organizational advantage. Academy of Management Review, 23(2), 242-266. https://doi.org/10.5465/AMR.1998.533225

Naranjo-Valencia, J., Jiménez, D., \& Sanz-Valle, R. (2012). ¿Es la cultura organizativa un determinante de la innovación en la empresa?. Cuadernos de Economía y Dirección de la Empresa, 15(2), 63-72. https://doi.org/10.1016/j.cede.2011.07.004

Nonaka, I. (1994). A dynamic theory of organizational knowledge creation. Organization Science, 5(1), 14-37. https://doi.org/10.1287/orsc.5.1.14

Partington, D. (2000). Building grounded theories of management action. British Journal of Management, 11(2), 91-102. https://doi.org/10.1111/1467-8551.00153

Ordóñez de Pablos, P. (2003). Intellectual capital reporting in Spain: A comparative view. Journal of Intellectual Capital, 4(1), 61-81. https://doi.org/10.1108/14691930310455397

Peteraf, M. (1993). The Cornerstones of Competitive Advantage: A Resource-Based View. Strategic Management Journal, 14(3), 179-191. https://doi.org/10.1002/smj.4250140303

Petty, R., \& Guthrie, J. (2000). Intellectual capital literature review. Journal of Intellectual Capital, 1(2), 155-176. https://doi.org/10.1108/14691930010348731

Porter, M. (1980). Industry Structure and Competitive Strategy: Keys to Profitability. Financial Analysts Journal, 36(4), 30-41. https://doi.org/10.2469/ faj.v36.n4.30

Rasmussen, C. (2014). Intangible resources as drivers of high growth. International Journal of Innovation Management, 18(4), 1-20. https://doi.org/10.1142/S1363919614500212 
Rastogi, P. (2002). Knowledge management and intellectual capital as a paradigm of value creation. Human Systems Management, 21, 229-240.

Romer, P. (1990). Endogenous technological change. Journal of Political Economy, 98(5), 71-102 https://doi.org/10.1086/261725

Roos, G., \& Roos, J. (1997). Measuring your Company's Intellectual Performance. International Journal of Strategic Management, 30(3), 413-426.

Roquebert, J., Phillips, R., \& Westfall, P. (1996). Markets vs. Management: what "drives" profitability?. Strategic Management Journal, 17(8), 653-664. https://doi.org/10.1002/(SICI)1097-0266(199610)17:8<653::AIDSMJ840>3.0.CO;2-O

Rubin, P. (1973). The Expansion of Firms. Journal of Political Economy, 81(4), 936-949. https://doi.org/10.1086/260089

Rumelt, R. (1991). How much does industry matter?. Strategic Management Journal, 12(4), 167-185. https://doi.org/10.1002/smj.4250120302

Saint-Onge, H. (1996). Tacit knowledge the key to the strategic alignment of intellectual capital. Planning Review, 24(2), 10-16. https://doi.org/10.1108/eb054547

Schultz, T. (1993). The Economic Importance of Human Capital in Modernization. Education Economics, 1(1), 13-19. https://doi.org/10.1080/09645299300000003

Schumpeter, J. (1912). The Theory of Economic Development. Oxford: Oxford University Press.

Scott, J., \& Pascoe, G. (1986). Beyond the Firm and Industry Effects on Profitability in Imperfect Markets. The Review of Economics and Statistics, 68(2), 284-292. https://doi.org/10.2307/1925508

Strauss, A., \& Corbin, J. (1990). Basics of qualitative research: grounded theory, procedures and techniques. California: Sage Publications.

Stewart, T., \& Zadunaisky, D. (1998). La nueva riqueza de las organizaciones: El capital intelectual. Madrid: Editorial Granica .

Sveiby, K. (1997). The new organizational wealth. Managing and measuring knowledge-based assets. San Francisco, CA: Berret-Koehler Publishers, Inc.

Sveiby, K. (2001). A knowledge-based theory of the firm to guide in strategy formulation. Journal of Intellectual Capital, 2(4), 344-358. https://doi.org/10.1108/14691930110409651

Teece, D., Pisano, G., \& Shuen, A. (1997). Dynamic capabilities and strategic management. Strategic Management Journal, 18(7), 509-533. https://doi.org/10.1002/(SICI)1097-0266(199708)18:7<509::AID-SMJ882>3.0.CO;2-Z

Todericiu, R., \& Stăniț, A. (2015). Intellectual Capital - The Key for Sustainable Competitive Advantage for the SME's Sector. Procedia Economics and Finance, 27(22), 676-681. https://doi.org/10.1016/S2212-5671(15)01048-5

Wernerfelt, B. (1984). A resourcei-based view of the firm. Strategic Management Journal, 5(1), 171-180. https://doi.org/10.1002/smj.4250050207

Wiig, K. (1997). Integrating intellectual capital and knowledge management. Long Range Planning, 30(3), 399-405. https://doi.org/10.1016/S0024-6301(97)90256-9

Winter, S. (2003). Understanding dynamic capabilities. Strategic Management Journal, 24(10), 991-995. https://doi.org/10.1002/smj.318

Yang, S., \& Kang, H. (2008). Is synergy always good? Clarifying the effect of innovation capital and customer capital on firm performance in two contexts. Technovation, 28(10), 667-678.

https://doi.org/10.1016/j.technovation.2008.01.004

Zahra, S., Sapienza, H., \& Davidsson, P. (2006). Entrepreneurship and dynamic capabilities: A review, model and research agenda. Journal of Management Studies, 43(4), 917-955. https://doi.org/10.1111/j.1467-6486.2006.00616.x 
Zheng, W. (2010). A social capital perspective of innovation from individuals to nations: Where is empirical literature directing us?. International Journal of Management Reviews, 12(2), 151-183. https://doi.org/10.1111/j.14682370.2008.00247.x

Intangible Capital, 2018 (www.intangiblecapital.org)

\section{(c) (1) \$}

Article's contents are provided on an Attribution-Non Commercial 4.0 Creative commons International License. Readers are allowed to copy, distribute and communicate article's contents, provided the author's and Intangible Capital's names are included. It must not be used for commercial purposes. To see the complete license contents, please visit https://creativecommons.org/licenses/by-nc/4.0/. 